\title{
A case of Hirayama disease treated with laminectomy and duraplasty without spinal fusion
}

\author{
I. Arrese; J.J. Rivas; J. Esteban*; A. Ramos** and R.D. Lobato
}

Department of Neurosurgery, Neurology* and Neuroradiology**. Hospital Universitario 12 de Octubre. Madrid. Spain.

\section{Sumary}

Introduction. Juvenile amyotrophy of the distal upper extremity (JADUE) is a rare disease afecting young males. Since neck flexion has been thought to be the cause of the spinal cord damage, cervical orthosis, spinal fusion by an anterior or posterior approach and duraplasty in combination with posterior spinal fusion have been proposed as treatment of JADUE. We are presenting the case of a patient with JADUE who was surgically treated with duraplasty without spinal fusion, thus avoiding the compression of the spinal cord without limitation of cervical movement.

Case. A previously healthy 19-year-old man presented with insidious onset of weakness in the left forearm and hand for the past year. On MRI, during neck flexion, the posterior dura showed anterior displacement that compressed the cervical spinal cord. The dura was opened linearly from $\mathrm{C} 3$ to $\mathrm{C} 6$, observing the herniation of the spinal cord through the opening. Duraplasty was performed in order to increase the room of the spinal cord. No spinal fusion was performed.

Discussion. The postoperative course was uneventful. Clinical deterioration stopped following operation and two years later unchanged as compared to the preoperative one.

KEY WORDS: Hirayama disease. Juvenile amyotrophy. Laminectomy. Duraplasty.

Presentación de un caso de enfermedad de Hirayama tratado mediante laminectomía y duraplastia sin fusión espinal

\section{Resumen}

Introducción. La amiotrofia juvenil de extremidad superior distal (AJESD) es una rara enfermedad que afecta a varones jóvenes. Desde que la flexión del

Recibido: 21-04-09. Aceptado: 23-09-09 cuello fue reconocida como causa de la enfermedad, han sido empleadas como tratamiento las ortosis cervicales, la fusión vertebral y la duraplastia asociada a fusión. Presentamos un caso de AJESD que fue tratado quirúrgicamente mediante duroplastia sin fusión vertebral cervical, de tal forma que la compresión sobre la médula fue eliminada sin limitar la movilidad del cuello.

Caso. Varón de 19 años con un cuadro lentamente progresivo de debilidad en antebrazo y mano izquierda. A la exploración se apreció moderada atrofia de los músculos interóseos dorsales izquierdos. El electromiograma mostraba denervación aguda de los músculos interóseos dorsales, así como cambios reinervativos crónicos en otros músculos. La MR objetivó desplazamiento anterior de la duramadre cervical cuando el cuello era flexionado que provocaba compresión medular a dicho nivel. Se realizó laminectomía y duroplastia $\mathrm{C} 3-\mathrm{C} 7$ sin añadir ninguna técnica encaminada a la fusión vertebral.

Discusión. El postoperatorio cursó sin incidencias y la progresión sintomática cesó. Dos años tras la cirugía el paciente continua sin cambios.

PALABRAS CLAVE: Enfermedad de Hirayama. Amiotrofia juvenil. Laminectomía. Duroplastia.

Introduction

Juvenile amyotrophy of distal upper extremity (JADUE), also known as Hirayama disease, is characterized by 1) muscular atrophy that appears predominantly in males 15-25 years old; 2) usually sporadic, though rarely familial, occurrence; 3) limited muscular atrophy from the hand to forearm, excepting for the brachioradialis, which shows oblique amyotrophy over the forearm; 4) a lack of definite sensory disturbance and abnormal deep tendon reflex; and 5) a slowly progressive clinical course ${ }^{4,10}$.

Since neck flexion has been thought to be the cause of the spinal cord damage, cervical orthosis, spinal fusion by an anterior or posterior approach and duraplasty in com- 


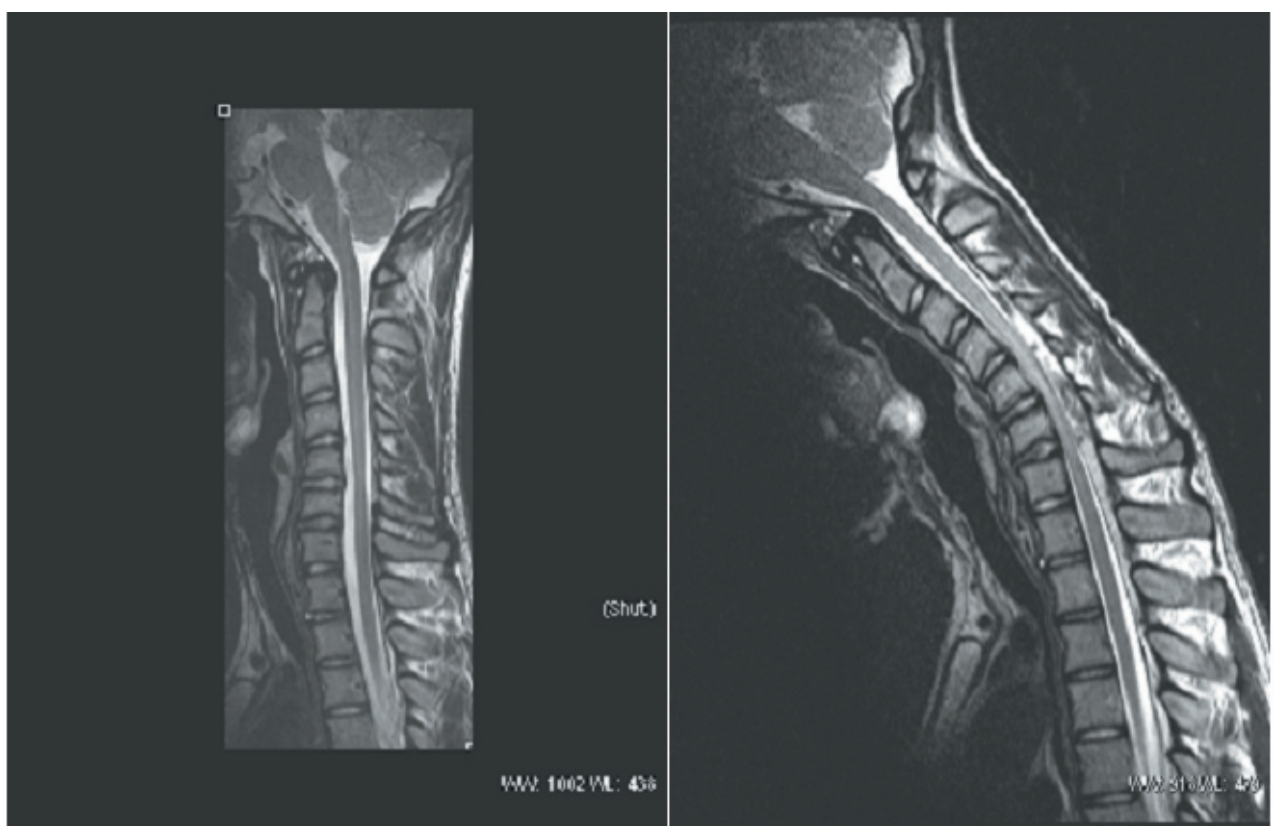

Figure 1: Left: T2 MRI in extended position does not show significative alteration. Right: T2 MRI during neck flexion shows anterior displacement of the posterior dura compressing the cervical spinal cord. Moreover, the posterior epidural space becomes larger and the flow voids were exaggerated. An evident spinal cord hyperintensity can be observed.

bination with posterior spinal fusion have been proposed as treatment of $\mathrm{JADUE}^{7}$. However, the imaging findings observed in dynamic studies have shown, not only the absence of hypermobility in the cervical spine, but also the increase in the rigidity of the dura as a cause of spinal cord compression $^{2,3,5,7,9}$. Histopathological findings have also suggested that alterations in the laxity of the dural tissue are the basic cause leading to a repeated spinal cord compression and, thus, to spinal cord damage ${ }^{7}$.

We are presenting the case of a patient with JADUE who was surgically treated with duraplasty without spinal fusion, thus avoiding the compression of the spinal cord without limitation of cervical movement.

\section{Case report}

A previously healthy 19-year-old man presented with insidious onset of weakness in the left forearm and hand for the past year. He had also noticed fasciculations in his hand. There was not family history of neuromuscular disease. Physical examination showed moderate atrophy of the left interossei dorsalis manus muscles. Electromyography showed acute denervation of the left interossei dorsalis manus muscles and chronic reinnervative changes in the left abductor pollicis brevis, flexor pollicis longus, and flexor digitorum profundus. Nervus ulnaris and nervus medianus conduction velocities were within normal limits. MRI examination of the cervical spine with extension and flexion of the cervical spine was performed and, although there was no spinal cord compression in extended position neither on $\mathrm{T} 1$ nor on $\mathrm{T} 2$ sequences, during neck flexion, the posterior dura showed anterior displacement that displaced the cervical spinal cord (Fig. 1). Moreover, the posterior epidural space became larger and the flow voids in the posterior epidural space were exaggerated. An evident hiperintensity appeared on $\mathrm{T} 2$ sequence.

\section{Operation}

The patient was placed in a prone position with the head supported by a three-point pin headrest. The posterior dura mater was exposed by laminectomy from C3 to C7. During the laminectomy, an abnormally great epidural vascularity with difficult hemostatic control was found. The dura was opened linearly from $\mathrm{C} 3$ to $\mathrm{C} 6$, observing the herniation of the spinal cord through the opening. Duraplasty was performed in order to increase the room of the spinal cord. No spinal fusion was performed.

\section{Outcome}

The postoperative course was uneventful. Postoperative MRI, performed 3 months after surgery, documented the successful decompression of the spinal cord with the cervical flexion (Fig 2). Clinical deterioration stopped following operation and two years later unchanged as compared to the preoperative one.

\section{Discussion}

Our case shows that decompression of the cervical spinal cord segment can be achieved in JADUE by laminectomy and duraplasty without spinal fixation. To our knowledge, all surgical and non-surgical approaches previously included spine immobilization of the cervical spine segment in order to prevent flexion damage. Non-operative treatment with a cervical orthosis has been practiced with some effect and there have been cases managed with spinal fusion by 


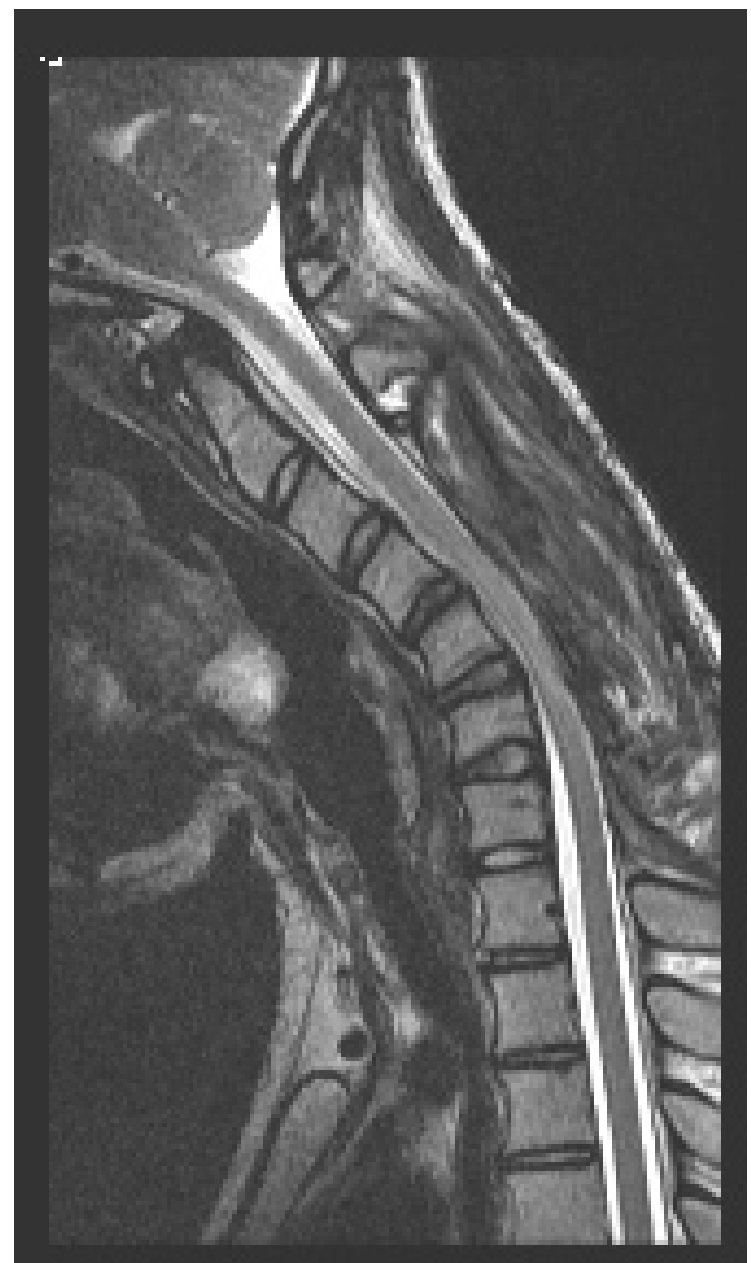

Figure 2: Control T2 MRI performed 3 months after surgery shows a good decompression of the spinal cord. Hyperintensity of the spinal cord during neck flexion is not observed.

an anterior or posterior approach ${ }^{10}$. In addition, Konno et. al. ${ }^{7}$ reported five patients with JADUE treated surgically with duraplasty in combination with posterior spinal fusion in order to control two physiopathological components: the dynamic factor by cervical fixation and the static factor by duraplasty. In our case, in which the spinal cord displacement was clearly observed only with flexion manoeuvres on dynamic MRI, we decided to discard cervical fixation. In this way, we achieved liberation of the spinal cord without limiting cervical motion. In a young patient with clinical evidence of hand and/or forearm muscle atrophy and asymmetric thinning of the cervical spinal cord, JADUE should always be suspected. Detection of focal spinal cord atrophy in such a patient should prompt to perform a dynamic evaluation of the cervical spine. Forward migration of the posterior surface of the dura mater with compression of the spinal cord on MRI obtained with flexion of the cervical spine is characteristic ${ }^{2,3}$.

Although neck flexion has been implicated in the physiopathology of JADUE (the disorder was termed "flexion myelopathy" by $\mathrm{Kikuchi}^{5}$, the underlying mechanism is still controversial ${ }^{1,5,8,9}$. Some authors consider that JADUE is not a flexion-induced cervical myelopathy, but an intrinsic motor neuron disease. The physiopathological influence of the flexion mechanism could support the effectiveness of the spinal fixation but, the natural history of the disease, which may arrest spontaneously several years after the onset $^{4}$, questions the benefit to the surgical procedure. However, after seeing the MRI findings in our and other cases, it is difficult to reject that dural compression accompanying flexion movements represents an actual insult to spinal cord. Hence, we support the mechanical theory for explaining spinal cord damage and thus we recommend surgical treatment as the best option in patients affected by JADUE.

\section{References}

1. Ammendola, A., Gallo, A., Iannaccone, T., Tedeschi, G.: Hirayama disease: three cases assessed by $\mathrm{F}$ wave, somatosensory and motor evoked potentials and magnetic resonance imaging not supporting flexion myelopathy. Neurol Sci 2008; 29: 303-311.

2. Baba, Y., Nakajima, M., Utsunomiya, H., Tsuboi, Y., Fujiki, F., Kusuhara, T., Yamada, T.: Magnetic resonance imaging of thoracic epidural venous dilation in Hirayama disease. Neurology 2004; 62: 1426-1428.

3. Chen, C.J., Chen, C.M., Wu, C.L., Ro, L.S., Chen, S.T., Lee, T.H.: Hirayama disease: MR diagnosis. AJNR 1998; 19: 365-368.

4. Hirayama, K.: Juvenile muscular atrophy of distal upper extremity (Hirayama disease). Intern Med 2000; 39: 283-290.

5. Hirayama, K.: Juvenile muscular atrophy of distal upper extremity (Hirayama disease) focal cervical ischemic poliomyelopathy. Neuropathology 2000; 20 Suppl: 91-94.

6. Kikuchi, S., Shinpo, K., Nii, no M., Higashi, T., Tashiro, K.: Cervical myelopathy due to a "tight dural canal in flexion" with a posterior epidural cavity. Intern Med 2002; 41: 746748 .

7. Konno, S., Goto, S., Murakami, M., Mochizuki, M., Motegi, H., Moriya, H.: Juvenile amyothrophy of the upper extremity: pathologic findings of the dura mater and surgical management. Spine 1997; 22: 486-492.

8. Misra, U.K., Kalita, J., Misra, V.N., Phadka, R.V., Hadique, A.: Effect of neck flexion on $\mathrm{F}$ wave, somatosensory evoked potentials and magnetic resonante imaging in Hirayama disease. J Neurol Neurosurg Psychiatry 2006; 77 : 695-698.

9. Restuccia, D., Rubino, M., Valeriani, M., Mirabella, M., Sabatelli, M., Tonali, P.: Cervical cord dysfunction during 
neck flexion in Hirayama disease. Neurology 2003; 60: 19801983.

10. Tashiro, K., Kikuchi, S., Itoyama, Y., Tokumaru, Y., Sobue, G., Mukai, E., Akiguchi, I., Nakashima, K., Kira, J., Hirayama, K.: Nationwide survey of juvenile muscular atrophy of distal upper extremity (Hirayama disease) in Japan. Amiotroph Lateral Scler 2006; 7: 3845 .

\section{Comentarios al trabajo: Diagnóstico y tratamiento de un paciente con Enfermedad de Hirayama de I. Arrese y cols.}

La Enfermedad de Hirayama es infrecuente, caracterizándose por causar atrofia unilateral de la mano y del antebrazo. A pesar que se da, por lo general, en personas jóvenes, también se ha descrito en personas adultas ${ }^{1}$. Las causas que originan esta clínica no están muy claras, como bien refieren los autores, describiéndose en la literatura la falta de elasticidad de la dura madre ${ }^{2}$ que provocará en los movimientos de flexión fenómenos de compresión méduloradicular e incluso algunos autores ${ }^{1}$ describen que no hay diferencias en los potenciales evocados somatosensoriales como motores, tanto en la posición cervical neutra como cuando se realizan estas pruebas con la columna en flexión ${ }^{1}$. Respecto al tratamiento de esta patología, se considera principalmente el abordaje quirúrgico posterior con apertura de la dura mas duroplastia junto con la fusión de la columna. En el caso que describen los autores se practicó también abordaje posterior con apertura de la dura más duroplastia sin realizar fusión. En este último punto sería conveniente tener en cuenta que el paciente presentaba una imagen cervical rectificada y el realizar múltiples laminectomías
Arrese, I.; Rivas, J.J.; Esteban, J.; Ramos, A.; Lobato, R.D.: A case of Hirayama disease treated with laminectomy and duraplasty without spinal fusion. Neurocirugía 2009; 20 : 555-558.

Correspondence: Ignacio Arrese Regañon. Servicio de Neurocirugía. Hospital 12 de Octubre. Av. Córdoba s/n. 28041 Madrid. Spain. Email: iarrese14@yahoo.es

(desde C3 a C7) podría provocar a largo plazo inversión de la curva, a pesar de que clínicamente después de dos años no hubiera progresado la sintomatología. En conclusión, creo que el trabajo es de interés por la infrecuencia de esta patología y que habría que valorar cuando se presentasen pacientes como el caso descrito.

\section{Bibliografía}

1. Ammendola, A., Gallo, A., Iannaccone, T., Tedeschi, G.: Hirayama disease: three cases assessed by $\mathrm{F}$ wave, somatosensory and motor evoked potentials and magnetic resonance imaging not supporting flexion myelopathy. Neurol Sci 2008; 29: 303-311.

2. Konno, S., Goto, S., Murakami, M., Mochizuki, M., Motegi, H., Moriya, H.: Juvenile amyothrophy of the upper extremity: pathologic findings of the dura mater and surgical management. Spine 1997; 22: 486-492. 